\title{
GAMBARAN PENGGUNAAN MASKOT SEBAGAI LOGO BAGI MEREK (STUDI KASUS: DUNIA FANTASI)
}

\author{
Anny Valentina ${ }^{1}$, Herwindo Tando ${ }^{2}$ \\ ${ }^{1}$ Fakultas Seni Rupa dan Desain Universitas Tarumanagara, Jakarta \\ Email: annyv@fsrd.untar.ac.id \\ ${ }^{2}$ Fakultas Seni Rupa dan Desain Universitas Tarumanagara, Jakarta \\ Email: euwin_tan76@yahoo.com
}

\begin{abstract}
ABSTRAK
Menggunakan maskot sebagai karakter dalam iklan sangat umum di dunia usaha. Maskot juga digunakan untuk mewakili identitas kelompok atau pelayanan umum. Tujuan dari penelitian ini adalah untuk mengetahui gambaran penggunaan maskot sebagai logo kepada konsumen, bagaimana maskot akan mendorong konsumen untuk memberikan sikap positif terhadap merek dengan berbagi pengalaman dan gambaran perilaku konsumen terhadap merek, hingga akhirnya konsumen melakukan advokasi terhadap merek. Penelitian ini menggunakan metode kualitatif dengan cara mewawancarai konsumen. Konsumen dibagi menjadi 3 (orientasi pada : keluarga, kelompok muda / remaja, dan pasangan). Dalam penelitian ini, peneliti menggunakan data dari wawancara dan membandingkan data ini dengan teori-teori yang berkaitan dengan brand destination, karakter dari wisatawan, logo, maskot dan merek itu sendiri.
\end{abstract}

Kata kunci: merek, maskot, logo, perilaku konsumen, advokasi

\section{PENDAHULUAN}

\section{Latar Belakang}

Ada banyak tempat yang bisa kita temukan di Jakarta sebagai tempat rekreasi. Jakarta sebagai ibukota Indonesia memiliki berbagai tujuan mulai dari taman kota hingga taman bermain, kebun binatang, mal, dan taman hiburan. Tujuan ini akan ramai pada akhir minggu, musim liburan sekolah dan sekolah. Salah satu taman hiburan terbesar di Indonesia adalah Dunia Fantasi atau dikenal dengan Dufan. Sebenarnya popularitas Dufan sebagai taman hiburan belum bisa menandingi popularitas monas atau TMII. Sebagai salah satu taman hiburan terbesar di Indonesia Dufan saat ini memiliki banyak pesaing baru, yang paling dekat adalah Jungleland, setelah itu di Bandung ada studio (taman hiburan dalam ruangan), dan kampung Gadjah, dan yang terbaru adalah taman Jatim.

Dufan yang selama ini kita kenal diwakili oleh sebuah maskot berupa kera bekantan, maskot ini diambil dari hewan yang tinggal di kawasan yang sekarang merupakan lokasi dufan, selain itu penggunaan hewan ini sebagai salah satu usaha pelestarian hewan yang memang dilindungi ini. Sebagai tokoh yang dipilih untuk merepresentasikan sebuah merek, sebuah maskot diharapkan mampu mewakili nilai-nilai yang dimiliki oleh sebuah merek, sehingga bisa menjadi alat komunikasi yang efektif bagi sebuah merek.

Dewasa ini positioning, diferensiasi dan merek saja ternyata tidak cukup. Konsumen dan produsen berada pada sebuah posisi yang sejajar. Sebuah merek harus memiliki karakter, dengan karakter yang kuat, akan memberikan support pada kekuatan sebuah merek juga, konsumen saat ini mencari merek yang mampu mewakili karakternya. Karena itu diharapkan personality dari merek Dufan seharusnya mampu ditampilkan dalam maskot yang diwakilinya.

Maskot Dufan sering kali digunakan bersamaan dengan logo dufan sendiri, karena itulah maskot Dufan sudah menjadi satu kesatuan logo yang tidak dapat dipisahkan dari merek Dufan sendiri. 
Sebuah merek yang memiliki karakter yang kuat yang mampu mewakili personality merek nya akan membuat merek tersebut bisa menjadi perbincangan di konsumennya, sehingga bisa menciptakan pengalaman pribadi yang unik untuk konsumennya dan pada akhirnya konsumen dengan senang hati melakukan advokasi terhadap merek.

\section{Rumusan Masalah}

Bagaimanakah penggunaan maskot sebagai logo bagi merek yang dimiliki Dufan saat ini dalam menciptakan pengalaman pada konsumen hingga konsumen melakukan advokasi bagi merek?

\section{METODE PENELITIAN}

\section{Objek dan Lokasi}

Penelitian ini mengambil lokasi penelitian di Dunia Fantasi Taman Impian Jaya Ancol, khususnya area Dunia Fantasi. Dunia Fantasi yang merupakan lokasi yang memiliki wahana permainan cukup banyak dengan lokasi yang cukup luas.

\section{Teknik Pengumpulan Data}

Data dalam penelitian ini terdapat dua jenis data yaitu data primer dan data sekunder. Data primer merupakan data yang diambil langsung dari lapangan berupa hasil wawancara, dokumentasi lapangan dan foto kondisi lapangan yang di ambil di lokasi Dunia Fantasi Ancol. Sedangkan data sekunder adalah data yang didapat dari berbagai referensi atau pustaka yang mendukung.

Melalui proses observasi dan wawancara dengan pengelola, partisipan dalam penelitian ini yang adalah pengunjung Dunia Fantasi Ancol digolongkan menjadi 3 orientasi (keluarga, kelompok muda/remaja, dan pasangan). Pengambilan data wawancara dengan pengunjung dalam penelitian ini dilakukan secara accidental (bertemu dan bersedia untuk diwawancara).

\section{Prosedur Penelitian}

\section{Tahap \\ Pra Lapangan \\ (Rancangan) \\ Tahap Lapangan
(Observasi, Data,
Wawancara dan
Dokumentasi)
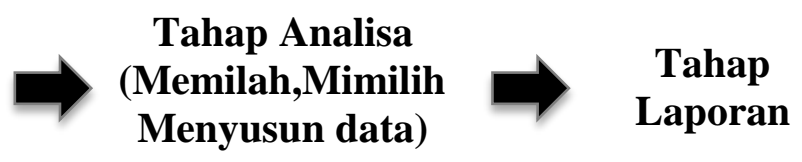

\section{HASIL DAN PEMBAHASAN}

\section{Profil pengunjung dan Pariwisata}

Melalui wawancara, pengunjung berpendapat Dufan adalah tempat rekreasi yang menyenangkan untuk mencari aktivitas sebatas melepas rutinitas, rekreasi dan bersenang senang, terbukti dengan data yang didapatkan, mereka mengunjungi Dunia Fantasi seusai musim ujian sekolah dan memasuki musim liburan sekolah, atau hanya melepas rutinitas kantor untuk pengunjung dewasa.

Mereka mengunjungi destinasi berupa tourist spot yang menawarkan banyak atraksi wisata baru dan yang bersifat massal, karena dari beberapa yang diwawancara pengunjung banyak yang datang berkelompok, misalnya kelompok dari sekolah atau kantor. Dunia Fantasi sebagai tempat wisata berlokasi di area Taman Impian Jaya Ancol, merupakan area yang cukup luas dan memiliki fasilitas yang cukup lengkap, mulai dari akomodasi, berupa hotel untuk pengunjung 
dari luar Jakarta. Akomodasi memang tidak terletak di dalam area Dunia Fantasi seperti yang ada di Disneyland, tempat wisata sejenis dengan Dunia Fantasi yang cukup terkenal dan menjadi tujuan wisatawan dunia. Terdapat juga jasa boga baik di luar area Dufan maupun didalam area Dufan, untuk di dalam Area Dufan, jasa boga cukup lengkap, pada saat pengambilan data, promosi yang sedang berlangsung adalah tiket termasuk tiket untuk makanan, hal ini tentulah menarik pengunjung untuk berkunjung ke Dufan. Selain 2 hal tersebut unsur pariwisata lain yang menarik pengunjung adalah Dufan selalu memberikan update atraksi wisata baru sebagai pilihan untuk pengunjungnya, serta yang tak kalah penting dari sebuah tempat pariwisata adalah toko cinderamata. Gambar 1 menunjukkan contoh cinderamata.

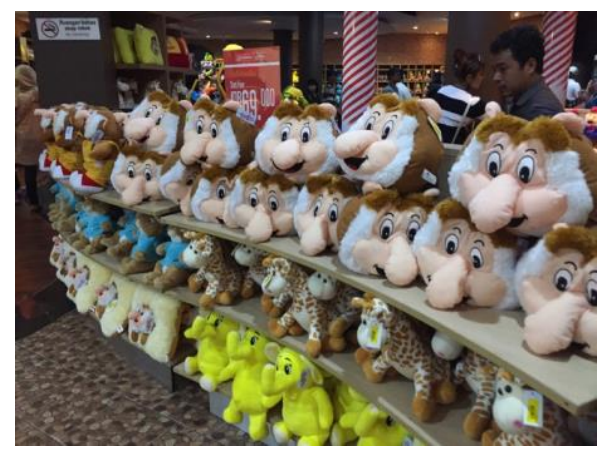

Gambar 1. Contoh cinderamata yang dijual di area Dunia Fantasi Sumber: Dokumentasi Pribadi

Beberapa dari mereka mencari dan mau untuk membeli cinderamata untuk dijadikan kenangkenang-an, beberapa mau membeli jika barang tersebut sederhana dan bisa digunakan kapan saja, ada yang ingin membeli sesuatu yang bisa dipakai seperti kaos, tidak jarang juga yang tidak mau membeli karena cinderamata dinilai untuk anak anak saja.

\section{Maskot dan Logo}

Kera Bekantan asal Kalimantan Indonesia dipilih sebagai karakter yang mewakili Dunia Fantasi dengan alasan kelangkaan hewan tersebut dan keberadaan hewan ini yang hanya ada dan hidup di Indonesia. Selain kelangkaan hewan ini, menurut Ketua Departemen Perencanaan dan Desain Dunia Fantasi serta Ketua Divisi Kreatif Departemen Perencanaan PT. Jaya Ancol. Tbk dan Manual Mutu Dunia Fantasi, alasan dipersonifikasinya Kera Bekantan ini juga karena pengaruh dari theme park / wanaha permainan Disneyland yang dikenal dengan Mickey Mousenya. Berbeda dengan karakter Dufan yang memang sengaja dibuat untuk wahana, karakter Mickey sendiri sudah cukup dikenal jauh sebelum Disneyland dibangun.

Kera bekantan yang dipersonifikasi ini menjadi karakter yang mewakili Dufan, baik menjadi maskot maupun menjadi satu kesatuan dengan logo dufan yang berupa logotype. Untuk sebuah wahana seperti Dufan memang ada beberapa kepentingan yang bisa didapatkan brand dari penggunaan sebuah maskot. Kehadiran maskot dianggap mampu memperkuat sisi promosi dan branding. Meletakkan maskot di setiap media promosi iklan maupun media lainya dianggap memudahkan masyarakat untuk mengenal dan memahami kepribadian atau identitas dari sebuah brand. Kehadiran sebuah maskot juga dianggap mempermudah seseorang untuk mengingat sebuah brand. Dari data yang dikumpulkan, pengunjung banyak yang mengetahui keberadaan dari maskot dufan tersebut. Banyak pula yang berfoto bersama. 

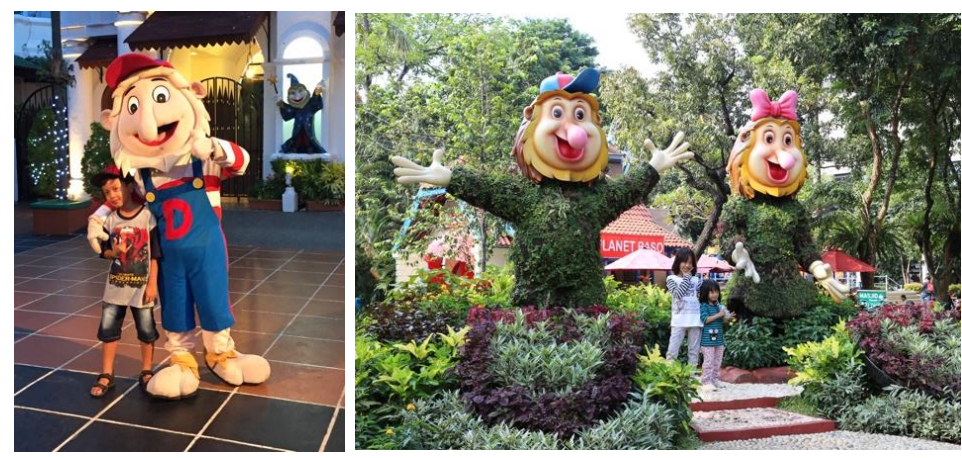

Gambar 2. Kegiatan pengunjung yang berfoto bersama dengan karakter Dunia Fantasi Sumber Gambar: Dokumentasi Pribadi, 2017

Melalui foto bersama ini, sebuah brand akan dipromosikan melalui konsumen, tidak jarang konsumen yang kemudian akan mengunggah hasil foto bersama maskot ini di media sosial yang mereka miliki, hal ini terasa akan sangat menguntungkan bagi sebuah brand, karena dipromosikan secara langsung oleh konsumen. Dari data yang didapat, dufan juga menjual maskotnya dalam bentuk cideramata. Gambar 2 menunjukkan kegiatan foto bersama.

Tetapi sangat disayangkan banyak di antara pengunjung yang tidak mengetahui bahwa maskot Dufan adalah seekor kera bekantan. Personifikasi memang salah satu cara yang dipilih jika digunakan hewan sebagai tokoh utama, hal ini dilakukan karena personifikasi membuat kita merasa lebih dekat dengan tokoh, karena personifikasi menggunakan gaya bahasa yang mempersamakan benda atau hewan dengan manusia, memiliki sifat, kemampuan, pemikiran dan perasaan seperti yang dimiliki dan dialami oleh manusia. Beberapa hal yang perlu dipehatikan ketika membuat karakter kartun adalah visualisasi karakter yang memiliki ciri khas dan kepribadian, bahasa tubuh yang jelas, serta mimik wajah yang mampu mewakili emosi dan perasaan dengan kuat dan tepat.

Logo sendiri harus unik, karena melalui keunikan itulah logo bisa memancarkan kekuatan identitasnya. Walaupun itu bukan satu satunya hal penting, sebuah logo yang banyak memiliki kemiripan dengan logo yang lain akan menimbulkan banyak masalah dikemudian hari. Logo Dufan sendiri terdiri dari tulisan "Dufan" atau yang biasa dikenal sebagai Logotype.

Ditinjau dari logotype, yang digunakan, hal penting dari penggunaan tipografi adalah legibility dan readability. Anatomi huruf merupakan salah satu hal penting. Dipilih dari anatomi script, membuat logo Dufan sangat spesifik dan berbeda dengan yang lain. Jenis huruf ini seolah mengikuti tulisan tangan, sehingga terkesan lebih dekat dan akrab. Hal yang patut diwaspadai ketika menggunakan huruf script adalah tingkat keterbacaan, karena jika terlalu tipis akan sulit terbaca. Tetapi logo type Dufan menggunakan karakter tebal (bold), huruf tebal digunakan untuk menarik perhatian pembaca dan biasanya memang digunakan untuk judul, sehingga bisa menimbulkan kontras. Gambar 3 menunjukkan logotype Dufan. 


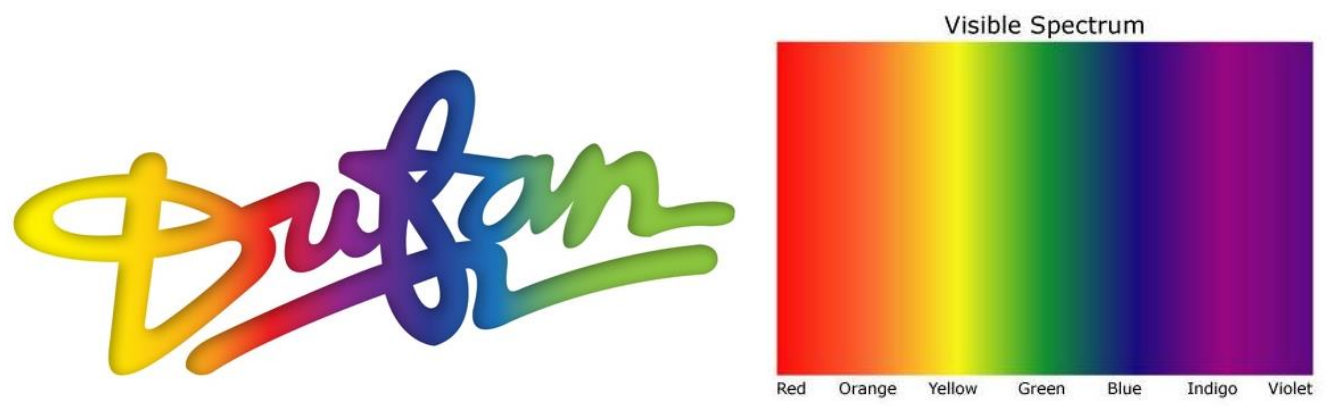

Gambar 3. Logotype Dufan dan spektrum warna

Sumber Gambar: https://www.ancol.com/destinasi/dunia-fantasi, 2017

Warna yang digunakan juga tidak satu warna, tetapi menggunakan spektrum warna, sehingga terkesan vibrant. Disadari atau tidak, warna merupakan hal penting dalam mempengaruhi seseorang mengambil keputusan saat membeli barang, selain itu warna juga meningkatkan brand recognition. Pemilihan warna yang tepat sangat penting bagi sebuah perusahaan. Penggunaan kata spektrum awalnya dalam ilmu alam adalah di bidang optis untuk menggambarkan pelangi warna. Hal ini bisa diartikan sebagai analogi sebuah keadaan untuk menggambarkan rentang keadaan, misalnya berjuta warna yang bisa ditemukan di dufan, atau rentang kegiatan yang banyak yang bisa ditemukan di dufan.

\section{Merek}

Sebagai sebuah merek, Dufan memang harus mempertimbangkan penggunaan karakter sebagai image yang mewakilinya. Sebuah brand image yang efektif akan mempu mencerminkan:

- Membangun karakter produk dan memberikan value proposition.

○ Menyampaikan karakter produk secara unik sehingga berbeda dari pesaing.

o Memberikan kekuatan emosional lebih dari kekuatan rasional.

Ketika Dufan mampu membangun brand image yang baik, hal itu akan meningkatkan value preposition, menjadi sangat penting untuk penyampaikan karakter produknya melalui brand image karena dengan demikian akan memberikan kekuatan emosional yang lebih dari kekuatan rasional yang dimiliki produk tersebut. Melalui kekuatan emosional membuat konsumen mampu mengasosiakan serangkaian hal positif dalam pikirannya ketika mereka memikirkan brand tersebut. Hal ini bisa dilihat dari wawancara yang dilakukan, pengunjung Dufan mengasosiakan citra yang positif tentang Dufan. Dari pengunjung didapatkan bahwa Dufan adalah "Tempat": rekreasi; ngumpul; liburan; yang seru; yang keren; dengan wahana; yang penuh dengan permainan.

Hal ini tentu sangat penting bagi sebuah brand ketika diasosiasikan dan dipersepsikan secara positif di benak konsumennya. Asosiasi menjadi penting bagi sebuah brand karena melalui asosiasi bisa membentuk citra sebuah merek. Asosiasi dapat membantu proses mengingat kembali informasi yang berkaitan dengan produk, khususnya selama proses pembuatan keputusan untuk melakukan pembelian. Misalnya Dufan diasosiasikan dengan tempat rekreasi, maka ketika konsumen khusunya yang telah berkeluarga atau grup akan memilih tempat untuk melakukan rekreasi, maka akan terlintas di benaknya, salah satu tempat rekreasi adalah Dufan, atau mencari tempat liburan, maka nama Dufan akan menjadi salah satu yang dipertimbangkan. 
Untuk konsumen anak muda atau pasangan yang mencari sebuah tempat yang keren yang penuh dengan wahana permainan yang seru dan keren, akan juga diingat Dufan. Salah satu keuntungan dari asosiasi ini salah satunya akan menunjang kesuksesan proses pemasaran. Asosiasi yang baik membuat konsumen lebih bisa cepat diyakinkan dan percaya pada sebuah brand, untuk membuat asosiasi yang baik saat ini tidak hanya melalui pencitraan saja, tapi juga bisa dilakukan melalui pengalaman yang menyenangkan dari konsumen dengan brand. Saat ini banyak brand yang berlomba untuk membuat kegiatan yang melibatkan konsumen secara langsung dengan cara ikut berpartisipasi (consumer experience). Selain itu yang juga penting adalah, asosiasi membuat brand unik, sehingga berbeda dengan brand lain, hal ini bisa menjadi salah satu alasan konsumen memilih merek.

Dari wawancara ditemukan ketika diminta mengasosiasikan Dufan dengan sebuah objek atau gambar konsumen mengasosiasikan dufan dengan: Wahana permainan; Badut; Tempat yang bisa membawa pengunjung berkeliling dunia; Boneka (menunjuk pada maskot dufan, tetapi tidak tau apa bentuknya); Dinosaurus; T-rex.

Melalui wawancara didapat hanya sedikit dari konsumen yang mengasosiasikan Dufan dengan image-nya kera bekantan. Beberapa malah menyebutkan tokoh kera bekantan ini adalah badut atau kurcaci. Sangat penting untuk memberitahukan brand image kepada konsumen, dengan harapan konsumen memiliki persepsi terhadap brand sehingga mempengaruhi cara pandang konsumen dalam melihat brand, sehingga ketika konsumen dihadapkan pada sebuah stimulus dari brand, maka akan menghasilkan respon yang positif, kemudian melakukan aksi yang positif juga terhadap merek. Dari hasil penelitain keputusan pembelian didasarkan pada persepsi dan bukan fakta fakta faktual. Karena itulah pembentukan persepsi konsumen melalui brand image menjadi sangat penting.

\section{KESIMPULAN DAN SARAN}

\section{Kesimpulan}

Dufan dianggap sebagai tempat rekreasi yang menyenangkan untuk mencari aktivitas sebatas melepas rutinitas, rekreasi dan bersenang senang, dan biasanya mengunjungi Dunia Fantasi seusai musim ujian sekolah dan memasuki musim liburan sekolah, atau hanya melepas rutinitas kantor untuk pengunjung dewasa. Kebanyakan pengunjung tertarik mengunjungi Dufan karena banyaknya promosi dan informasi Dufan yang selalu update (update tentang atraksi wisata baru). Sebagian dari pengunjung ada mencari dan mau untuk membeli cinderamata untuk dijadikan kenang-kenang-an, beberapa mau membeli jika barang tersebut sederhana dan bisa digunakan kapan saja, ada yang ingin membeli sesuatu yang bisa dipakai seperti kaos, tidak jarang juga yang tidak mau membeli karena souvenir dinilai untuk anak anak saja.

Kera bekantan asal Kalimantan Indonesia dipilih sebagai maskot Dufan dengan alasan kelangkaan hewan tersebut dan keberadaan hewan ini yang hanya ada dan hidup di Indonesia. Penggunaan gaya personifikasi karena pengaruh dari theme park / wanaha permainan Disneyland yang dikenal dengan Mickey Mousenya. Kera bekantan yang dipersonifikasi ini menjadi karakter yang mewakili Dufan, baik menjadi maskot maupun menjadi satu kesatuan dengan logo dufan yang berupa logotype. Untuk sebuah wahana seperti Dufan memang ada beberapa kepentingan yang bisa didapatkan brand dari penggunaan sebuah maskot. Kehadiran maskot dianggap mampu memperkuat sisi promosi dan branding. Meletakkan maskot di setiap media promosi iklan maupun media lainya dianggap memudahkan masyarakat untuk mengenal dan 
memahami kepribadian atau identitas dari sebuah brand. Kehadiran sebuah maskot juga dianggap mempermudah seseorang untuk mengingat sebuah brand. Sebagian besar pengunjung mengetahui keberadaan dari maskot dufan tersebut tetapi kurang mengetahui binatang asli dari maskot Dufan, akan tetapi banyak yang senang berfoto bersama. Logo Dufan memenuhi syarat logo yang unik karena menggunakan anatomi script yang membuat logo Dufan sangat spesifik dan berbeda dengan yang lain. Jenis huruf ini seolah mengikuti tulisan tangan, sehingga terkesan lebih dekat dan akrab. Warna yang digunakan juga tidak satu warna, tetapi menggunakan spektrum warna, sehingga terkesan vibrant. Warna logo Dufan adalah spektrum yang bisa dianalogikan sebagai sebuah keadaan untuk menggambarkan rentang keadaan, misalnya berjuta warna yang bisa ditemukan di dufan, atau rentang kegiatan yang banyak yang bisa ditemukan di dufan.

Hanya sedikit dari konsumen yang mengasosiasikan Dufan dengan image-nya kera bekantan. Beberapa malah menyebutkan tokoh kera bekantan ini adalah badut atau kurcaci. Dengan membangun brand image yang baik, maka value preposition Dufan akan meningkatkan.

\section{Saran}

Cinderamata bisa dijadikan sebagai nilai tambah bagi Dufan tentu saja dengan mempertimbangkan jenis cinderamata yang dijual, sehingga semua kalangan pengunjung bisa tertarik untuk membeli, mengambil contoh taman bermain sekelas Disneyland yang begitu cermat mengolah cinderamata-nya, sehingga bisa menjadi nilai tambah dari taman bermainnya. Tidak sedikit bahkan pengunjung yang sengaja mengunjungi hanya untuk berbelanja cinderamata, tentu saja ini memberikan keuntungan bagi taman bermain itu sendiri.

Selain itu untuk menunjang nilai dari sebuah brand, maskot menjadi penting, Mickey mouse contohnya, pengunjung rela membeli souvenir dengan gambar atau bentuk Mickey Mouse dan teman temannya, selain memeberikan nilai lebih pada penjualan cinderamata, melalui maskot, brand akan turut dipromosikan oleh konsumen. Melihat perilaku konsumen saat ini yang suka berbagi di media sosial, konsumen saat ini akan mengunggah hasil foto bersama maskot ini di media sosial yang mereka miliki, hal ini terasa akan sangat menguntungkan bagi sebuah brand, karena dipromosikan secara langsung oleh konsumen. Untuk itu perlu menjadi pertimbangan bagi Dufan untuk lebih mengenalkan tokoh dalam maskotnya dalam berbagai bentuk, misalnya cerita tentang maskot, atau fakta tentang maskot, pengolahan tokoh yang lebih aplikatif.

Selain itu ada beberapa hal yang perlu dipehatikan ketika membuat karakter kartun adalah Visualisasi karakter yang memiliki ciri khas dan kepribadian, bahasa tubuh yang jelas, serta mimik wajah yang mampu mewakili emosi dan perasaan dengan kuat dan tepat.

Sebagai sebuah brand, Dufan memang harus mempertimbangkan penggunaan karakter sebagai image yang mewakilinya. Sebuah brand image yang efektif akan mempu mencerminkan :

- Membangun karakter produk dan memberikan value proposition.

- Menyampaikan karakter produk secara unik sehingga berbeda dari pesaing.

- Memberikan kekuatan emosional lebih dari kekuatan rasional.

Ketika Dufan mampu, menjadi sangat penting untuk penyampaikan karakter produknya melalui image dari mereknya karena dengan demikian akan memberikan kekuatan emosional yang lebih dari kekuatan rasional yang dimiliki produk tersebut. Melalui kekuatan emosional membuat 
konsumen mampu mengasosiakan serangkaian hal positif dalam pikirannya ketika mereka memikirkan brand tersebut.

Bagi sebuah brand sangat penting ketika diasosiasikan dan dipersepsikan secara positif di benak konsumennya. Asosiasi menjadi penting bagi sebuah brand karena melalui asosiasi bisa membentuk citra sebuah merek. Asosiasi yang baik membuat konsumen lebih bisa cepat diyakinkan dan percaya pada sebuah brand, untuk membuat asosiasi yang baik saat ini tidak hanya melalui pencitraan saja, tapi juga bisa dilakukan melalui pengalaman yang menyenangkan dari konsumen dengan brand.

Perlu dipertimbangkan bagi brand sekelas Dufan untuk kegiatan yang lebih melibatkan konsumen secara langsung dengan cara ikut berpartisipasi (consumer experience). Karena melalui acara acara aktivasi semacam ini brand image akan semakin kuat.

\section{Ucapan Terima Kasih (Acknowledgement)}

Terima kasih kami sampaikan kepada Pengelola Dunia Fantasi yang telah memberikan kesempatan untuk melakukan wawancara dan memberikan informasi untuk kebutuhan penelitian. Terima kasih kepada Direktur Penelitian dan Pengabdian kepada Masyarakat Universitas Tarumanagara yang telah memberikan kesempatan untuk melakukan penelitian ini, juga kepada seluruh ketua dan staff di DPPM Untar yang telah membatu dan mendukung, kepada redaktur Jurnal Muara. Ucapan terima kasih juga untuk Yessudhana yang membantu proses dokumentasi lapangan, serta untuk mahasiswa yang membatu mengumpulkan sampling berupa wawancara (Fitry, Brigit, Alex dan Veren).

\section{REFERENSI}

Aaker, D. (1991). Managing brand equity; capitalizing on the value of brand name. New York, NY: Free Press.

Bayer, H., Karl G., dan Kenya H. (2009). Graphic design theory readings from the field. New York, NY: Princeton Architectural Press.

Color Bomb. (2013). Brown Color Image Example, http://www.colorcombos.com/tags/colors/brown (diakses 12 November 2014).

Color Bomb. (2013). Hex Web Color, http://www.colorcombos.com/colors/BA6222 (diakses 12 November 2014).

Gilbert, J. (2013). Warm Colors?, http://www.pinterest.com/jenlovesmichael/warm-colors/ (diakses 11 November 2014).

Healey, M. (2008). What Is Branding? New York, NY: Rockport.

Kotler, Phillip dan Gary Amstrong. 2001. Prinsip-Prinsip pemasaran, jilid 2, edisi ke-8. Jakarta: Penerbit Erlangga.

Muzack, Z. (2013). psikologi pariwisata dan kepribadian wisatawan, http://zackyeducations.blogspot.com/2013/01/psikilogi-pariwisata.html(diakses 3 Oktober 2014).

Ouwersloot, H. and Anamaria, T. (2001). Brand personality creation through advertising, dalam Maxx Working Paper 2001-01, February 2nd 2001

Product Finishing (2013). White Stay Atop of Cars Color Rank. http://www.pfonline.com/blog/post/white-stays-atop-the-worlds-car-colorranks (diakses 11 November 2014).

Rustan, S. (2010). Font \& tipografi. Jakarta: Gramedia Pustaka Utama.

Rustan, S. (2010). Layout, Dasar dan Penerapannya, Cetakan Kedua. Jakarta: Gramedia Pustaka Utama. 
Sarwono, J. dan Lubis, H. (2007). Metode riset untuk desain komunikasi visual. Yogyakarta: Andi.

SCI i-color creation (2014). Inilah Trend Warna di Tahun 2014, http://scipusat. blogspot.com/2013/04/inilah-warna-trend-di-tahun-2014.html(diakses 11 November 2014).

Siregar, AS (2012). Brand Destination http://repository.usu.ac.id/bitstream/123456789/33920/4/Chapter\%20II.pdf (diakses 6 Oktober 2014).

Social Psychology for Social Good (2010). Tools for Changing The World, http://toolsforchangingtheworld.com/let-us-make-ourselves-perfectlyclear/ (diakses 20 November 2014).

Tenbears (2011). Hard to Read Typography, http://www.coolastenbears.com /hard-to-readtypography-7 (diakses 20 November 2014). 